\title{
Geography of Rural Enterprise Banking and Microfinance Institutions in Bangladesh
}

\author{
Azim Uddin Mahmud \\ Antoni F. Tulla \\ Universitat Autònoma de Barcelona. Departament de Geografia \\ azim123@bdcom.com \\ antoni.tulla@uab.cat
}

\begin{abstract}
In remote areas of Bangladesh, it can be difficult for entrepreneurs, businesses and farmers to obtain needed bank loans, as banks are typically located in and around administrative centres. In addition, the banks have limitations in their product design (credit and savings) and have mostly avoided the challenges of rural enterprises. During the 1970s, the concept of the Microfinance Institution (MFI) emerged, based on the non-governmental organization model and favouring locations in rural areas not far from the administrative centres and rural markets. In this untapped market, MFIs grew by taking an institutional good practices approach and offering products designed to cater to low-income households and enterprises, although they still face legal constraints in holding public savings deposits. In addition, although the MFI reaches less accessible areas because of its organization pattern, its attempts to upscale MFI credit are not widely successful due to both the unwillingness and inability of the existing microfinance client pool to repay loans. Therefore, it is important to explore which entity (bank or MFI) has an advantageous geographic distribution and institutional good practices to meet the needs of rural enterprise.
\end{abstract}

Keywords: Microfinance; MFI and Bank Location; Rural Finance; Applied Geography; Bangladesh.

Resum. Geografia de la banca i les institucions financeres de microcrèdits entorn de les empreses rurals a Bangla Desh

En aquest article es pretén explicar les dificultats de les empreses i explotacions agràries en àrees remotes de Bangla Desh per accedir als crèdits que necessiten per dur a terme la seva activitat econòmica. La localització dels bancs en àrees rurals remotes de Bangla Desh mostra 
la mateixa distribució dels centres administratius. A la dècada dels anys setanta del segle xx va començar a aparèixer la figura de la «institució financera de microfinances» (MFI), basada en les organitzacions no governamentals (ONG) i amb intenció d'establir-se a prop dels centres administratius i dels mercats rurals. Els bancs van evitar majoritàriament les empreses rurals a causa de les limitacions que tenien en el disseny dels seus productes (crèdit i estalvi). En aquest mercat sense explotar, les MFI van créixer per la seva actitud més accessible i pel disseny de productes financers més adequats per aprovisionar les empreses i les famílies amb ingressos baixos. Tanmateix, les MFI han hagut de fer front a problemes legals per poder participar en els dipòsits públics d'estalvi. L'increment del crèdit concedit per les MFI no ha estat gaire satisfactori a causa tant de la política de concessió de crèdits de les institucions com de la incapacitat de l'actual grup de clients de microcrèdits per tornar els préstecs. Per tant, és important explorar quina entitat (banc o MFI) mostra una distribució espacial i unes bones pràctiques que afavoreixi les necessitats de l'empresa rural. Paraules clau: microfinances; localització de bancs i MFI; finances rurals; geografia aplicada; Bangla Desh.

Resumen. Geografía de la banca y las instituciones financieras de microcréditos alrededor de las empresas rurales en Bangladesh

En este artículo se pretende explicar las dificultades de las empresas y explotaciones agrarias en áreas remotas de Bangladesh para acceder a los créditos que precisan para llevar a cabo su actividad económica. La localización de los bancos en áreas rurales remotas de Bangladesh sigue básicamente la misma distribución de los centros administrativos. Durante la década de los años setenta del siglo xx empezó a incidir la figura de la «institución financiera de microfinanzas» (MFI), basada en organizaciones no gubernamentales (ONG) y con intención de establecerse en las áreas rurales no muy lejos de los centros administrativos y de los mercados rurales. Los bancos evitaron en su mayor parte las empresas rurales, ya que tenían limitaciones en el diseño de sus productos (crédito y ahorros). En este mercado sin explotar, las MFI crecieron a través de su situación más accesible y con el diseño de productos financieros más adecuados para abastecer a las empresas y las familias de bajos ingresos. Sin embargo, las MFI han tenido que enfrentarse a problemas legales para poder participar en los depósitos públicos de ahorros. El incremento del crédito concedido por las MFI no ha sido muy satisfactorio debido tanto a la política de concesión de créditos de las instituciones financieras como a la incapacidad del actual grupo de clientes de microcréditos para devolver los préstamos. Por lo tanto, es importante explorar qué entidad (banco o MFI) tiene una distribución espacial y unas buenas prácticas que favorezcan las necesidades de la empresa rural.

Palabras clave: microfinanzas; localización de bancos y MFI; finanzas rurales; geografía aplicada; Bangladesh.

Résumé. Géographie de la banque et des institutions financières de microcrédits autour des entreprises rurales au Bangladesh

Cet article tente d'expliquer les difficultés que rencontrent les entreprises et les exploitations agricoles dans les zones isolées du Bangladesh pour accéder aux crédits nécessaires à la réalisation de leur activité économique. La localisation des banques dans les territoires ruraux isolés du Bangladesh suit essentiellement la même distribution que celle des centres administratifs. Les années 70 ont vu l'apparition de la figure de "l'Institution financière de microcrédits " (MFI) basée sur des organisations non gouvernementales (ONG), dans l'intention de s'établir dans les zones rurales, à proximité des centres administratifs et des 
marchés ruraux. Les banques ont évité en grande partie les entreprises rurales du fait de leurs limitations en termes de design de produits (crédit et épargne). Dans ce marché encore inexploité, les MFI se sont développées du fait de leur meilleure accessibilité et grâce au design de produits financiers en meilleure adéquation avec les entreprises et les familles aux revenus faibles. Cependant, les MFI ont dû faire face à des problèmes légaux afin de pouvoir participer à des dépôts d'épargne publique. L'augmentation des crédits accordés par les MFI n'a pas été très satisfaisante à cause de la politique de concession des crédits des institutions et de l'incapacité de l'actuel groupe de clients de microcrédits à rembourser les prêts. Il est par conséquent important de déterminer quelle entité, (banque ou les MFI), offre une distribution spatiale et de bonnes pratiques favorisant les besoins de l'entreprise rurale.

Mots-clés: micro finances; localisation des banques et MFI; finances rurales; géographie appliquée; Bangladesh.

\author{
Summary \\ 1. Introduction 5. Geographical Concentration/ \\ 2. Rural Economic Geography in \\ Distribution of Bank Branches and MFIs \\ Bangladesh \\ 6. Conclusions \\ 3. Relevant Theoretical Issues \\ Bibliographical references
}

4. Geography of MFI in Bangladesh

\title{
1. Introduction
}

Two types of financial institutions regarding banking coexist in Bangladesh, the formal banking institutions with universal banking services, Microfinance Institutes (henceforth, MFI) for informal microfinancing and few semiformal institutes with specific objectives. The degree of formalities of these types sometimes overlap few fields and scopes. The characteristics and objectives of these institutions vary, and exert a strong influence on the overall pattern of where financial institutions are located. Formal financial institutions are mostly based on market principles that enable them to survive in a given geographic context. In contrast, microfinancing entered into the society and the financial market through various philanthropic activities, and therefore differs from formal banks in policy, operation and sustainability. The primary objectives of microfinance are to eradicate poverty, create jobs, and help the poor and disadvantaged social groups. Through this process, microfinancing has become part and parcel of the financial geography of rural Bangladesh. Formal banks have comparatively less physical presence in remote rural areas and a conservative credit policy for rural entities (Beck et al., 2007; Beck et al., 2009). Since their introduction in the 1970s, the concept of microfinance has become so important to the nation's rural areas that this approach has achieved the formal status of Microfinance Institutes (MFIs). The expansion of MFIs and their programs gradually engulfed other financial activities in the rural areas. By 
2013, the total number of clients reached nearly 33 million, with deposits of 226.20 billion taka (2.31 million euros or 2.87 million US dollars) ${ }^{1}$ and 341 billion taka in outstanding loans to 27.66 million borrowers (MRA, 2013).

The rapid expansion of MFIs through the Grameen Model${ }^{2}$ in the 1990s, up to the present matured stage and subsequent turn to commercialization (Salim, 2013) in an effort to achieve sustainability (instead of remaining subsidy-dependent), attracted the attention of global academic and international development economists. At this point, a comparative study of banks and MFIs is needed to determine the optimum structure of future rural banking in Bangladesh. The conceptual framework of this paper is focused on the geographic distribution of MFIs and banks, and how their services cater to rural enterprises. In general, banks are considered as a universal service provider, while the MFIs concentrate on a few specific objectives rather than providing all necessary banking services. The MFIs are also involved with a wide range of financial activities for social development.

Due to the pervasive nature of MFIs and their programme-based social objectives, a wide range of academic and economic development practitioners have studied the phenomenon, including economists, sociologists, anthropologists, geographers and feminists. In the past four decades, the evolution of policy, procedure and programmes has reshaped the MFIs in ways that are not visible to the rural public they serve. The rapid globalization of the financial model, along with the global attention it attracts, has had a strong impact. Rapid changes in regulatory and operational policies have affected the data structure very quickly, even during the study period for the present research. Therefore, the study objective was limited to exploring which entity (bank or MFI) has the more advantageous geographic distribution and institutional good practices to meet the needs of rural enterprise in Bangladesh.

\section{Rural Economic Geography in Bangladesh}

Bangladesh is a poverty-ridden, liberal Muslim country in south Asia with a population of nearly 155 million, in 2012, and a surface area of $147,057 \mathrm{sq} . \mathrm{km}$. With a population density of 1,048 people per sq. $\mathrm{km}$., nearly $70.6 \%$ of the population lives in rural areas, engages in agro-economic activities (UNDP, 2012), and the vast majority are economically deprived according to national policy standards. The geography of administrative patterns in Bangladesh has shaped a "rural economic geography" that is highly influenced both by national administration policies and practices and by the market principles of financial services.

1. Taka is the currency of Bangladesh. 100 Bangladeshi Taka (BDT) $=1.02$ EUR or 1.27 USD (December 2014)

2. Grameen Bank, a specialized Microfinance Institute, was the pioneer of micro credit in Bangladesh and introduced group-based credit delivery to the poor who do not have any capability to produce physical collateral against loans; under micro-credit procedures, the liability is shouldered by all members of the group. 
Bangladesh has 7 administrative divisions (regions), with 64 zilas (districts) further divided into 483 upazilas (similar to counties) having 4498 unions, the lowest level of the hierarchy. In 1793, during the British Colonial period, districts were divided into police jurisdictions named thana (literally, "police station"). In 1982, the 599 thanas existing at the time were upgraded to upazilas with broader administrative responsibilities; in a few cases, thanas were combined to form a larger upazila.

Two different types of local government exist: in urban areas, 310 municipalities and 10 city corporations, and a hierarchy of rural councils ${ }^{3}$ (parishad), with district, upazila and union levels. Civil servants are posted to district and upazila administrative positions, observing a nearly parallel structure to that of urban areas, but the union parishad, the most local government, is an elected council (Ahsan, 2010; BBS, 2011; Paul and Goel, 2010). Since its founding in 1971, as the county has gradually become a development centre, thana headquarters have been considered a growth point for all sorts of economic, commercial and financial activities in rural areas. Rural branches of all commercial banks (public and private) are located in these areas (Mallick and Nabin, 2011) and MFIs (nongovernmental organizations, NGOs) have also focused there. The rural financial market in Bangladesh is a less impersonal environment than in urban areas, is less document-centred, traditionally based on "soft information", and is typically dualistic: formal and informal structures operate side by side (Hoff and Stiglitz, 1993; Zeller et al., 2001). The private commercial banks have seldom considered these rural sites and when they do launch there, it is only to meet the regulatory requirements of the Central Bank to open more branches in rural areas.

Most rural areas have poor infrastructure and low levels of development, with informal and primary-level economic activities. The fragile subsistence structure of the rural economic areas continues to grow, embedded with crisis and disparity. Another concern is local and regional sustainable development planning and its relation with rural development. However, if we look to more developed nations for models, the idea of sustainable development is gaining ground in local and regional development policies. "Smart growth" relies on the market to drive decisions, which may (or may not) promote sustainable development. Nonetheless, this is not a policy driven by grassroots interests but rather a form of representative development, wherein stakeholders and interest groups can shape development policy and its implementation. In contrast, the government's Local Agenda 21 (LA-21) relies on a democratic process to create goals, which are supported by the state regardless of market forces (Krueger, 2010).

In our case, if all the policies and institutional structures and cultures are in favour of rural enterprises, who enjoys a geographical advantage in rendering

3. Civil servants are posted to district and upazila administrative positions, observing a nearly parallel structure to that of urban areas, but the union parishad, the most local government, are an elected council (Ahsan, 2010; BBS, 2011; Paul and Goel, 2010). The election in other hierarchy is quite irregular. 
financial services, banks or MFIs? Spatial distribution and development agendas featuring financial inclusion are highly interrelated with the development process. For a rural enterprise, formal financial institutions are more fenced off and conservative due to policy structure and geographical access. Inequalities in spatial distribution and physical access excludes small firms and poor households in many developing countries like Bangladesh from using financial services, especially in rural areas, where distance is highly associated as a barrier (Beck et al., 2007; Beck et al., 2009). The spatial arrangement of financial intermediaries including MFIs in Bangladesh is important to the rural enterprise in need of financial services. Moreover, the absence of a perfect banking product for low-income households and microenterprises and the ability to target the relevant population to meet financial needs is an important determinant (Presbitero and Rabellotti, 2014). The presence of a financial intermediary having a sufficiently wide network of bank branches is not enough to meet the need. Access to credit also depends on the product available and its socially arranged opportunity structure (Beck and De la Torre, 2007; Beck et al., 2007, 2008; Uzzi, 1999). Examples of financially excluded people and small business are evident in the developed countries; consequently, the research community is increasingly focusing attention on the economically deprived, particularly after the global economic crisis of 2008. Mergers and acquisitions, rigid assessment criteria, policy restrictions, etc., have excluded them from loans, even jeopardizing relationship lending that could help weak and opaque small and medium enterprises (SMEs) (Appleyard, 2013; Dymski, 2013). On the other hand, providing services to rural enterprise requires physical proximity, and credit or debt servicing demands extra qualifications of the recipient because of the risk involved.

However, significant differences are observed within the ranks of the poor in rural areas. In Bangladesh, formal SMEs with a relatively solid foundation have access to commercial banks, while MFIs serve the extremely poor and the smallest enterprises. Between these two groups, a set of entities called "missing middle" enterprises are mostly underserved. Due to their heterogeneous characteristics, size, opaqueness and informal structure, they seem to always be excluded from formal financing. Secondly, they do not fall within the targeted objectives of MFI (Alamgir, 2009). Almost 90\% of farmers live below the subsistence level with a land holding of less than 2.5 acres (1.01 hectares) and are traditionally excluded from the MFI target clientele, typically the poor having less than 0.5 acre $(0.20$ hectares) of land. Lack of finance is the main concern for the larger landowners, as only around $27 \%$ of them get institutional credit. However, MFI lending to the poorer agricultural households for crops, livestock, etc., reaches up to 30\% (Faruqee, 2010; Mondol, 2010).

A recent trend of MFI expansion to commercial lending and up-scaling to cater to a wide range of business initiatives has changed the overall MFI lending profile drastically. It is quite evident that the MFI has expanded from its earlier objectives, changing the loan data structure (Figure 1) that originally attracted world attention. 


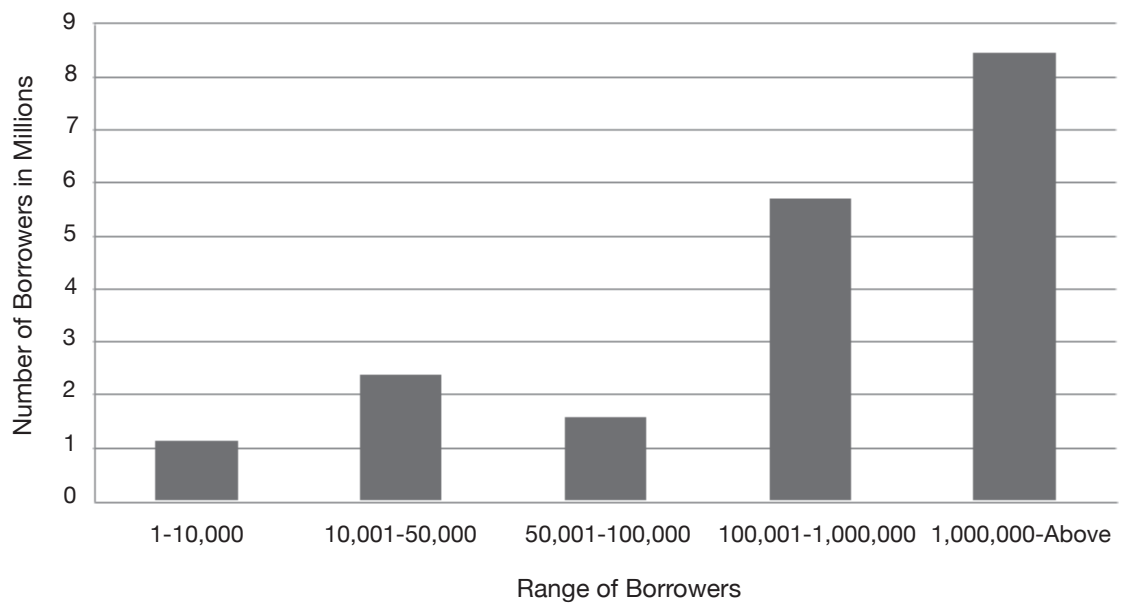

Figure 1. MFI Borrower Profile according to MFI size and MFI as stated by number of borrowers, 2013.

Source: <http://www.mra.gov.bd/images/mra_files/Publications/microcredit\%20in\%20bd14072014.pdf> (Page 2, Table 2). MRA (Microcredit Regulatory Authority-Data) Overview, 2013. Annual Report, MRA, Dhaka.

The number of borrowers in the above diagram is higher in the higher range of borrowers ceiling. These data are comparatively new, showing a recent trend, although there is no clear distinction between urban and rural loans. Moreover, there are relatively important outstanding micro-enterprise loans (amounting up to 50,000 taka each) that total about 38 billion taka, nearly $15 \%$ of the total outstanding microfinance loans (MRA Overview, 2011). Consequently, these data contradict the earlier MFI objectives, where commercialization was viewed as mission drift.

The exact number of the micro-SME (MSME) sector is difficult to quantify. Of the estimated 6 million MSMEs, almost 75\% (4.5 million) are located in rural areas (IFC and KFW, 2009). On the other hand, the capacity to absorb the incremental rural labour force in agriculture is extremely limited due to land scarcity; therefore, a dramatic occupational mobility from farm (agriculture) to non-farm activities is observed. Unfortunately, lack of credit is a major constraint in expanding non-farm enterprises (Hossain, 2004). Another problem is meeting the capital growth needs of microfinanced enterprises as they grow and are no longer part of the microfinance context. Even with a good supply of credit, the poorest of the poor microfinance clients remain underserved in Bangladesh. MFI clients that increase their activities seek larger loans, beyond the MFI capacity.

Furthermore, and with very few exceptions, most MFIs are constrained by a controversial regulatory topic in Bangladesh: public savings accounts. Therefore, they rely on external resources, including donors (Source of Fund, 
Table 1. Source of Funds of NGO-MFI, Bangladesh ${ }^{3}$

\begin{tabular}{|c|c|c|c|c|c|c|c|c|c|c|c|c|c|c|}
\hline \multirow[b]{3}{*}{ Source of Fund } & \multicolumn{14}{|c|}{ Amount in Million Taka } \\
\hline & \multicolumn{2}{|c|}{ June 2009} & \multicolumn{3}{|c|}{ June 2010} & \multicolumn{3}{|c|}{ June 2011} & \multicolumn{3}{|c|}{ June 2012} & \multicolumn{3}{|c|}{ June 2013} \\
\hline & Amount & $\%$ & Amount & $\%$ & G\% & Amount & $\%$ & G\% & Amount & $\%$ & G\% & Amount & $\%$ & G\% \\
\hline Client's Savings & 40,527 & 29.7 & 47,436 & 31.2 & 17.1 & 63,296 & 34.5 & 33.4 & 74,989 & 33.6 & 18.5 & 91,178 & 33,0 & 21.6 \\
\hline Loan from PKSF & 22,666 & 16.6 & 24,484 & 16.1 & 8.0 & 31,768 & 17.3 & 29.8 & 33,576 & 15.0 & 5.7 & 34,072 & 12.3 & 1.5 \\
\hline Bank Loan & 23,896 & 17.5 & 23,006 & 15.1 & -3.7 & 23,578 & 12.8 & 2.5 & 32,652 & 14.6 & 38.5 & 42,699 & 15.4 & 30.8 \\
\hline Donor Fund & 4,110 & 3.0 & 4,109 & 2.7 & -0.0 & 7,008 & 3.8 & 70.6 & 7,061 & 3.2 & 0.8 & 7,105 & 2.6 & 0.6 \\
\hline Cumulative Surplus & 36,282 & 26.6 & 42,339 & 27.8 & 16.8 & 50,299 & 27.4 & 18.8 & 65,438 & 29.3 & 30.1 & 83,262 & 30.1 & 27.2 \\
\hline Other Fund & 8,848 & 6.5 & 10,907 & 7.2 & 23.3 & 7,727 & 4.2 & -29.2 & 9,535 & 4.3 & 23.4 & 18,391 & 6.7 & 13.7 \\
\hline TOTAL & 136,309 & 100 & 152,281 & 100 & 11.7 & 183,676 & 100 & 20.6 & 223,251 & 100 & 21.5 & 276,707 & 100 & 20.4 \\
\hline
\end{tabular}

Source: Annual Report 2013, Microcredit Regulatory Authority (MRA). G. Growth; PKSF.

Table 1). The commercial banks in Bangladesh reach about 25 per cent of the total number of potential savings account holders; the rest of the market is untapped (Alamgir, 2009; IFC and KFW, 2009; World Bank, 2007). All these factors are at work within the geographical complexities and socioeconomic contexts of Bangladesh.

Table 1 shows the gradual growth of client deposits in the microfinance sector, and the growth of loans from commercial banks may be seen as new confidence. The gradual increase in the sector is a matter of great concern while there is a sharp rise and fall of the Donor Fund. The short period considered in Table 1 does not facilitate forecasting but it does give a picture of the present scenario. In addition, Grameen Bank, the largest MFI, is excluded from the data. It has nearly 79.84 billion taka in outstanding loans against deposits of 116.43 billion taka. Grameen Bank itself has 7.98 million borrowers; the rest of the microfinance sector has 19.31 million (MRA overview, 2010)

In the academic and policy sphere, most of the rural enterprise finance literature regarding "access to finance" either focuses on policy discussion or on the economic, institutional and legal obstacles. Geography is either neglected or poorly considered. The microcredit literature has generally paid limited attention to the geographic issues of distance and location (Presbitero and Rabellotti, 2014). Very few studies have focused on the geographical placement, outreach and success of MFIs (Ahlin et al., 2010; Ravallion and Wodon, 1997; Zeller et al., 2001).

The spatial arrangement of formal financial institutions, including MFIs, is a relatively new frontier in the academic arena in Bangladesh, where the MFIs added extra concerns as they grew as an interventional agent, exposing the existence of and expanding toward the untapped potential rural market. To date, the basic principle of establishing MFIs has been to provide financial services to the poor, with the mission of eradicating poverty rather than developing business activity. In time, the changing objectives of global policymakers have shifted toward enterprise and MFI sustainability along with poverty reduction initiatives. In that view, the geographical coverage of MFIs, 


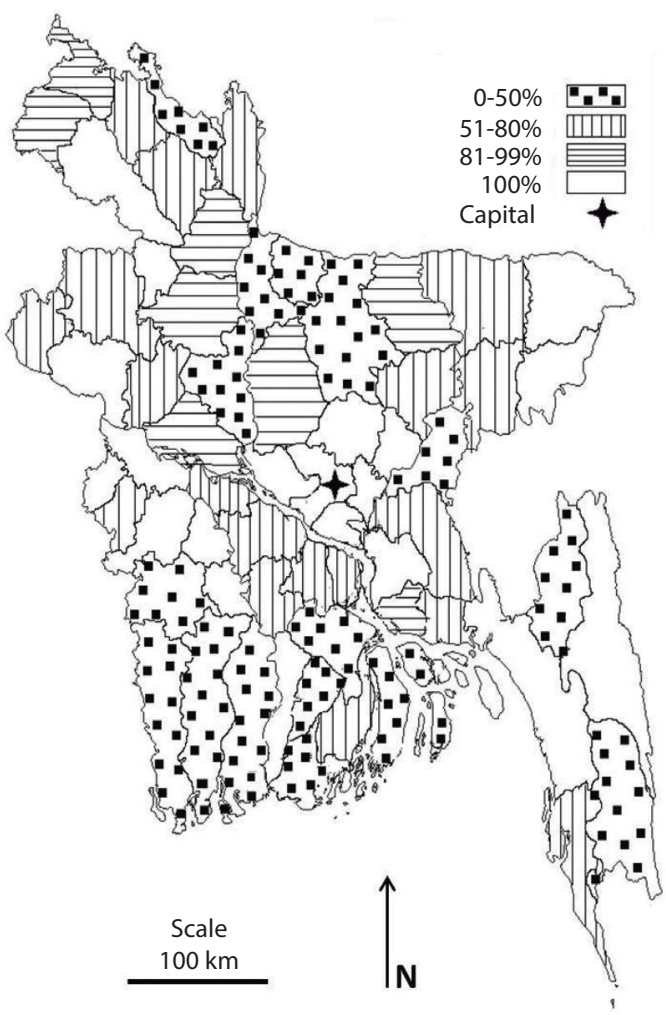

Figure 2. Percentage of poor people related to MFI-borrowers in Bangladesh.

Source: MAP (2014) at <http://mapsof.net/map/bangladesh-districts>. Produced from data in "Annual Report 2012" (MRA, 2013, Bengali Version, page 45). Authors' adaption.

counting the ratio of microfinance borrowers as a percentage of poor people in Bangladesh, is depicted by the MRA to forecast the gap filling between poor people's needs and the capacity to lend money (Figure 2).

After a long, historical start-up period of rise and fall, and after establishing a good network of banks and MFIs, the underlying problem of access to finance for rural enterprise and households remains mostly unresolved. A very geographical question is still mostly unexplored: who (banks or MFIs) will advance, either by up-scaling or by down-scaling, to tap this ignored rural enterprise sector? In light of these multidisciplinary discourses, this paper has two objectives: (1) To determine which geographical factors influence the location of remote rural bank branches and MFIs, and (2) to find out which of these two institutions (bank branches or MFIs) holds an advantageous position regarding spatial distribution, along with credit and savings services designed to reach rural enterprise and to challenge the current status. 


\section{Relevant Theoretical Issues}

From a global perspective, financial geography has long focused on global and national issues, such as globalization, international or national financial centres, and national financial systems (Clarke et al., 2005; Martin, 1999). There are also studies on sub-national financial systems based on metropolitan areas of developed economies (Marshall, 2004; Polese and Shearmur, 2004), or on the regional inequality of financial services (Klagge and Martin, 2005; Martin et al., 2005). Academic research on banking systems in the spatial perspective is well structured, focusing on regional banking and the development of saving zones in the European context (Gartner and Flögel, 2014). Research on market-based expansion, based on data from Spanish savings bank, their entry effect and sustainability, has been gaining ground (CarbóValverde, 2009; Dymski, 2013; Juan, 2002). However, Li and Xiongfei (2008) believe that financial geography and other relevant issues in less developed economies, particularly the less developed regions in these nations, remain the least explored. Few studies on bank lending to small firms have focused on how the organizational structure or the competitive environment of banks may affect small firms' access to credit (Berger and Udell, 1995; Petersen and Rajan, 1994, 1995). Evidence shows that rural and distant small firms are credit-constrained, even in developed nations (Alessandrini et al., 2010; Keeble, 1990).

The distribution of traditional financial institutions is uneven across the nations. Distance as a geographic factor has a substantial impact on financing enterprises. The whole lending environment may be dependent on distances between the lender and borrower and the competitor bank (Agarwal and Hauswald, 2010). On the other hand, a new dimension of distance (i.e. Operational Distance and Functional Distance ${ }^{4}$ ) has been discussed by Alessandrini et al. (2005), wherein the functional geographical organizational system has regulatory control over operational sites regarding loan approval, distance between financial institutions and SME, etc. Petersen and Rajan (2002) identified that distant applicants are credit rationed in the USA and argued that local lenders have an advantage in collecting soft information and strategically use this opportunity over distant lenders to serve SMEs. To mitigate informational problems raised by SMEs, a lending technology defined as "Relationship Lending" is used, wherein qualitative soft information is gathered on small enterprises and their owners through the passage of time. This approach was first formally sketched by Petersen and Rajan (1995).

Spain's retail banking sector offers an interesting example due to the country's large number of independent local markets to attract bank branches. The entrance of potential banks is basically determined by submarket characteristics and subsequently product design of new banks has to comply with the

4. The terminology was first introduced by Alessandrini et al. (2005) as a distance that separates the decisional centre from its operational point. Therefore, the power to decide to lend is preserved at the functional distance, away from local area of operation. 
strategic effect in the submarket (Juan, 2002). However, Spain has a bankingdriven financial structure to support the large SME sector, representing more than 99\% of total firms (Carbó-Valverde et al., 2009). The recent literature highlights the abrupt shock to the Spanish banking structure after the global economic crisis in 2008, which hampered the geographic expansion of the savings bank system; previously, the number of bank branches had doubled between 1989 and 2008 (Alamá and Tortosa, 2012). The global crisis jeopardized relationship banking in Spain, with a tendency to shift the credit flow to central institutions and reduce relationship banking in more peripheral regions, including low-income areas (Dymski, 2013).

Basically, financial institutions are likely to be located in rich areas rather than poor ones. The result is an absence of branch or delivery points in remote rural areas because the latter is adorned with bad geography: lower population density, poor infrastructure and low income levels, along with various socioeconomic limitations and discriminations (Beck and De la Torre, 2007; Pandula, 2011; Zeller et al., 2001). A geographically centralized financial system creates difficulties for firms - especially small firms - in peripheral regions to access funds. This is because of geographic distance as a physical barrier (Klagge and Martin, 2005; World Bank, 2007). In reality, a fully decentralized or a fully centralized financial system is rare. It is always difficult to identify the degree of this dimension (Gartner and Flögel, 2014). Even when financial institutions enter rural areas, they try to limit their exposure to agricultural finance and lend to the "collateral providers". They tend to be apathetic to agricultural credit, and this keeps rural areas vastly underserved (Rhyne and Christen, 1999).

A basic impediment is the asymmetric information flow between lenders and borrowers due to the distance between the two, which leads to credit rationing. In the case of a poor borrower, this invites collateral - and thus bank lending is infrequent in rural areas - as financial markets do not work in a space-neutral way (Klagge and Martin, 2005; Pellegrina, 2011). The process that excludes poor and disadvantaged social groups from financial access has a major impact on uneven development because it amplifies geographical differences on economic development and income. When the credit sanction is determined by the geography of income and wealth, this conditionally shapes the geography of financial access (Leyshon and Thrift, 1994). This can be related to power and its relationship with space. The unequal geographies of power underpin the gap of economic inequality. Power is exercised rationally through interactions with other places and is considered relational within its own context (Massey, 2009), so the development is influenced by power politics through resource distribution planning.

Other than location, remote rural enterprises have limited or no access to formal financial institutions because they do not usually have reliable credit histories and assets for collateral (Berger and Udell, 1995; 2006; Zeller et al., 2001). Microfinance procedures have broken various social conjectures, creating a group-based credit system of peer monitoring and social sanctions in 
low-income groups that basically lacked collateral. Their success was gained through the dynamic model developed in the lending technology of Grameen Bank in Bangladesh and "Banco Sol" in Bolivia (Chaves and Gonzalez-Vega, 1996; Gonzalez-Vega et al., 1996). In the last few decades, the expansion of MFIs has raised a response in the rural financial market. Microfinance has changed the lifestyles and economies of millions of low-income households and enterprises in the entire world by giving financial services to those who had no access to formal financial institutions (Armendariz and Morduch, 2005; Presbitero and Rabellotti, 2014). Thus, MFI growth occurred due to organizational (not financial) limitations and the absence of formal banks in remote areas. Sometimes these banks operate in the informal economic sector.

Government initiatives through public development banks in developing nations have also failed to meet the needs of low-income households (Chakravarty and Shahriar, 2010). To some extent, however, the Community Development Finance Institute (CDFI) in the UK offers a successful example of this approach. CDFI has gradually become instrumental in extending financial services to small businesses and people who are financially excluded by the mainstream financial institutes, particularly in disadvantaged areas (Appleyard, 2013; Leyshon and Thrift, 1994). The Microfinance revolution in Bangladesh also emerged from the reality of credit constraint for poor households or rural enterprises. It is a response to imperfect credit markets and helps people escape the clutches of unscrupulous moneylenders (Armendariz and Morduch, 2005; Mallick and Nabin, 2011; Pellegrina, 2011; Stiglitz, 1990). The coexistence of formal and informal institutions is viewed as a "Dual Financial System"; a common pattern of evolution in developing economies. In such a structure, banks enjoy a clear superiority in mobilizing funds but the informal sector is more able to gather soft information on borrowers (Tressel, 2003).

There is no correct micro-lending model in a given operating environment. And there are no two completely identical approaches to micro-lending. Experts have the opinion that microfinance is a kind of relationship lending and the large MFIs in Bangladesh basically rely on relationship metrics. The lender-borrower relationship, relationship-based lending and the information-collecting procedure are indicators of the types of lending technology (Chakravarty and Shahriar, 2010). The lender-borrower relationship is considered for relatively weak and opaque procedures with SMEs, mostly in the informal economic sector (Berger and Udell, 2006; Uchida et al., 2006). Alessandrini et al. (2010) emphasized the proximity of lender to borrower during the collection of soft information and argued the benefits of the loan officer who has personal contacts with the borrower, lives in the same community, knows people and firms who do business with the borrower, shares a common set of characteristics (cultural values, social norms and business language) and takes advantage of detailed environmental information. A few studies have also highlighted the location decision of MFIs in Bangladesh (Gauri and Fruttero, 2003; Khandker et al., 1995; Ravallion and Wodon, 1997; Zeller et al., 2001), discussed below, as a key element of micro-lending. 
Table 2. Growth of Scheduled Bank-Branch in Urban \& Rural Areas (1998-2012)

\begin{tabular}{|c|c|c|c|c|c|c|c|c|c|c|c|c|c|c|c|c|}
\hline \multirow[b]{3}{*}{ Year } & \multicolumn{8}{|c|}{ Urban Branch } & \multicolumn{6}{|c|}{ Rural Branch } & \multirow{2}{*}{\multicolumn{2}{|c|}{ Total }} \\
\hline & \multicolumn{2}{|c|}{$\mathrm{NCB}^{\star \star \star *}$} & \multicolumn{2}{|c|}{ Specialized } & \multicolumn{2}{|c|}{ Foreign } & \multicolumn{2}{|c|}{ Private } & \multicolumn{2}{|c|}{$\mathrm{NCB}^{\star \star \star}$} & \multicolumn{2}{|c|}{ Specialized } & \multicolumn{2}{|c|}{ Private } & & \\
\hline & $\mathrm{Br}^{*}$ & $G^{* *}$ & $\mathrm{Br}^{*}$ & $G^{\star \star}$ & $\mathrm{Br}^{*}$ & $G^{\star *}$ & $\mathrm{Br}^{\star}$ & $G^{* *}$ & $\mathrm{Br}^{*}$ & $G^{* *}$ & $\mathrm{Br}^{*}$ & $G^{\star \star}$ & $\mathrm{Br}^{*}$ & $G^{\star \star}$ & $\mathrm{Br}^{*}$ & $G^{\star \star}$ \\
\hline 1998 & 1336 & & 146 & & 29 & & 838 & & 2281 & & 1029 & & 312 & & 5971 & \\
\hline 1999 & 1336 & 0.0 & 147 & 0.7 & 31 & 6.9 & 898 & 7.2 & 2280 & 0.0 & 1030 & 0.1 & 316 & 1.3 & 6038 & 1.1 \\
\hline 2000 & 1336 & 0.0 & 150 & 2.0 & 34 & 9.7 & 940 & 4.7 & 2272 & -0.4 & 1063 & 3.2 & 324 & 2.5 & 6119 & 1.3 \\
\hline 2001 & 1335 & -0.1 & 149 & -0.7 & 33 & -2.9 & 985 & 4.8 & 2271 & 0.0 & 1067 & 0.4 & 342 & 5.6 & 6182 & 1.0 \\
\hline 2002 & 1313 & -1.7 & 150 & 0.7 & 31 & -6.1 & 1044 & 6.0 & 2170 & -4.5 & 1160 & 8.7 & 363 & 6.1 & 6231 & 0.8 \\
\hline 2003 & 1244 & -5.3 & 150 & 0.0 & 33 & 6.5 & 1099 & 5.3 & 2147 & -1.1 & 1164 & 0.3 & 383 & 5.5 & 6220 & -0.2 \\
\hline 2004 & 1241 & -0.2 & 151 & 0.7 & 37 & 12.1 & 1150 & 4.6 & 2147 & 0.0 & 1177 & 1.1 & 400 & 4.4 & 6303 & 1.3 \\
\hline 2005 & 1239 & -0.2 & 151 & 0.0 & 41 & 10.8 & 1207 & 5.0 & 2147 & 0.0 & 1189 & 1.0 & 428 & 7.0 & 6402 & 1.6 \\
\hline 2006 & 1238 & -0.1 & 154 & 2.0 & 48 & 17.1 & 1288 & 6.7 & 2146 & -0.1 & 1200 & 0.9 & 488 & 14.0 & 6562 & 2.5 \\
\hline 2007 & 1238 & 0.0 & 156 & 1.3 & 53 & 10.4 & 1376 & 6.8 & 2145 & -0.1 & 1203 & 0.3 & 546 & 11.9 & 6717 & 2.4 \\
\hline 2008 & 1240 & 0.2 & 157 & 0.6 & 56 & 5.7 & 1452 & 5.5 & 2146 & 0.1 & 1205 & 0.2 & 630 & 15.4 & 6886 & 2.5 \\
\hline 2009 & 1242 & 0.2 & 157 & 0.0 & 58 & 3.6 & 1594 & 9.8 & 2148 & 0.1 & 1208 & 0.3 & 780 & 23.8 & 7187 & 4.4 \\
\hline 2010 & 1243 & 0.1 & 157 & 0.0 & 62 & 6.9 & 1803 & 13.1 & 2161 & 0.6 & 1225 & 1.4 & 1007 & 29.1 & 7658 & 6.6 \\
\hline 2011 & 1245 & 0.2 & 166 & 5.7 & 63 & 1.6 & 1936 & 7.4 & 2192 & 1.4 & 1240 & 1.2 & 1119 & 11.1 & 7961 & 4.0 \\
\hline 2012 & 1253 & 0.6 & 175 & 5.4 & 65 & 3.2 & 2069 & 6.9 & 2225 & 1.5 & 1265 & 2.0 & 1270 & 13.5 & 8322 & 4.5 \\
\hline Acc. Gr & rowth & -6.3 & & 18.5 & & 85.4 & & 93.7 & & -2.4 & & 21.1 & & 151.3 & & 33.8 \\
\hline Growth & rate & -0.5 & & 1.3 & & 6.1 & & 6.7 & & -0.2 & & 1.5 & & 10.8 & & 2.4 \\
\hline
\end{tabular}

${ }^{*}$ Br: Branch; G*: Growth; ${ }^{* \star *}$ NCB: Nationalized Commercial Bank.

Source: Scheduled Bank Statistics, Bangladesh Bank, Quarterly, October-December, (1998-2012).

\section{Geography of MFI in Bangladesh}

In Bangladesh, microcredit programmes are run by NGOs, Grameen Bank, state-owned commercial banks, private commercial banks, and specialized programmes of the Bangladesh government. Other additional facilities beyond microcredit (i.e. insurance, remittance etc.) are recognized as microfinance. NGO-MFI structures differ a lot from the banking sector regarding their objectives and location pattern.

To get a fresh comparative picture of banks and MFIs, just a decade ago the financial sector of Bangladesh was considered "less diversified and relatively at an early stage of development" (Charitonenko and Rahman, 2002). Things have changed. Until 1982 all formal financial institutions in Bangladesh were government owned (Zeller et al., 2001). Nationalized Commercial Banks (NCBs), private banks and specialized ${ }^{5}$ banks have separate philosophies in choosing their branch locations. After the nation's 1971 independence from Pakistan, they opened branches in small towns and bazaars all over the country.

5. These are mainly development banks. Out of four specialized banks, Bangladesh Krishi Bank and Rajshahi Krishi Unnoyon Bank have a rural focus specifically on agriculture and these two are also considered as rural banks. 


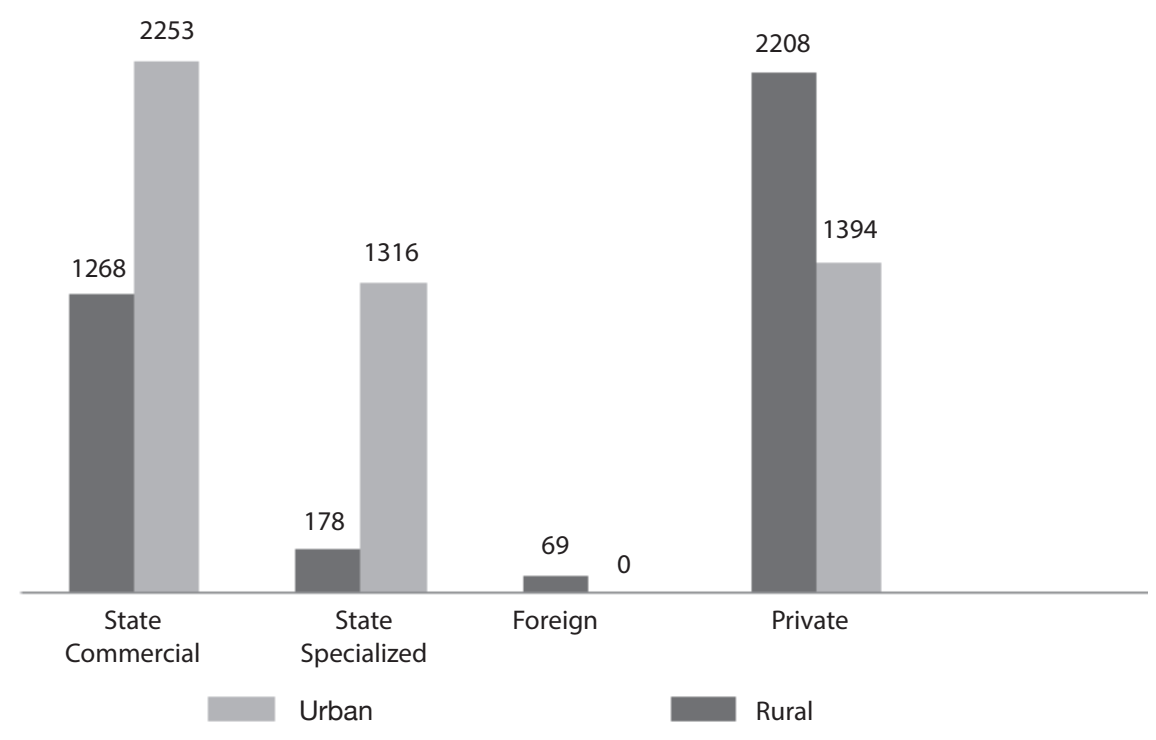

Figure 3. Urban \& Rural bank branches in December, 2013.

Source: Scheduled Bank Statistics, Bangladesh Bank, Quarterly, October-December, 2013.

Despite this large branch network in rural areas, most of them are not catering to the poor due to the collateral requirement (Figure 3). Basically, the two rural specialized banks were established to provide subsidized credit at the grassroots level beyond the limit of urban capture (Alamgir, 2009; Charitonenko and Rahman, 2002).

Banks have organized their branches by following administrative networks and focusing on well-endowed areas because they are guided by market principles; the role of commercial and foreign banks to reach poor households and microenterprises is very negligible (Alamgir, 2009; Beck and Demirgüç-Kunt, 2008; Khandker et al., 1995; Zeller et al., 2001). On the other hand, the commercial banks have channelled the available rural deposits to support urban credit needs (Ferrari, 2008).

The branch growth rate of Nationalized Commercial Banks (Table 2) was negative both in urban and rural areas $(-0.45 \%$ and $-0.17 \%$, respectively) in the period 1998-2012, although the trend started much earlier. Foreign banks have had no presence in rural areas but showed a growth rate of $6.1 \%$ in urban areas. Specialized banks were increasing at the rate of $1.32 \%$ and $1.51 \%$ in urban and rural areas, respectively; private banks had the highest growth rate both in urban and rural areas (6.69\% and $10.81 \%$, respectively). Typically, MFI branches are located in comparatively more remote rural areas than the rural bank branch; however, any municipal area is considered urban. Microcredit programmes of NGO-MFIs and Grameen Bank have infiltrated the rural financial market 
through various supportive programmes. During and immediately after the liberation struggle, NGOs like Bangladesh Rural Advancement Committee (BRAC), Proshika and the Association for Social Advancement (ASA) were established - in 1972, 1976, and 1978, respectively - with various development objectives. Later on, they added microfinance to their menu. The microcredit model was established through an action research plan by Nobel Laureate Professor Mohammad Yunus in the late 1970s. The early 1990s was an era of growth and rapid expansion all over the country. Before the inception of MFIs, microcredit was provided by rural co-operative societies; as the importance of MFIs increased, the role of banks and cooperatives in meeting rural credit needs declined. The formation of the Palli Karma Shahayak Foundation (PKSF) in 1990 as a funding organization for MFIs has changed the scenario sharply (Alamgir, 2009; Charitonenko and Rahman, 2002; Gauri and Fruttero, 2003; MRA Overview, 2013; Zaman, 2004).

Population density and ethnic, social and cultural homogeneity have played a vital role in MFIs gaining ground and expanding. In addition, the liberal Muslim community showed tolerance, which absolutely contrasts with other Muslim areas like Pakistan, Afghanistan, Egypt, the Middle East and North Africa, where they played a negative role. Moreover, visionary leadership and continuous donor support, at least at the beginning, smoothed the way in Bangladesh (Charitonenko and Rahman, 2002; Cull et al., 2009; Demirgüç-Kunt and Klapper, 2012; Gauri and Fruttero, 2003; Ravallion and Wodon, 1997; Rhyne and Christen, 1999; Zaman, 2004). This donor dependency in the early stage of MFIs indicated that their objectives were driven by altruistic motivations like alleviation of poverty, job creation, etc. in contrast to a standard business model.

The term "commercialization" has a negative image in rural society. In contrast, NGOs are supposed to be innovative, flexible and supportive to the poor instead of seeking profit. Even the government looks at dual objectives like profitability and poverty alleviation, taking a more political approach. Negative attitudes about NGOs, and others with a similar socioeconomic platform, affect NGO reputations; therefore, a fully commercial MFI - while perhaps more sustainable in the long-term - is controversial (Charitonenko and Rahman, 2002; Cull et al., 2009; Rhyne and Christen, 1999). In the mid-1970s, the popularity of microfinance in the global community was due to the underrepresentation of women in Bangladesh (Armendariz and Roome, 2008). However, empowerment of women in Bangladesh through microfinance is highly appreciated in the academic arena. A study in Sri Lanka by Aladuwaka and Momsen (2013) reported that microfinance empowers women by providing them bargaining power in family decision making and also helps to achieve other gains, although the outcome depends on socioeconomic and cultural background. Armendariz and Roome (2008) and Kato and Kratzer (2013) made similar claims. However, the overall idea has been opposed strongly by Karim (2008), who found that although women are the loan receiver in 95\% of cases, there is normally a husband or other male behind the scenes as the 
end user of the funds. Karim accused Professor Mohammad Yunus, the MFI founder, of hiding the truth and claimed that researchers and NGO officials censor this truth from public information for several reasons. One of these is to satisfy the western donors' mandate regarding economic participation by women.

Nonetheless, the managing director of a large NGO commented that "Commercialization may be possible in few countries where per capita income is at least US\$ 2,000.00 per year" (Charitonenko and Rahman, 2002). In a study of location decisions made by BRAC and Grameen Bank, Salim (2013) found inconsistency between branch placement decisions and the stated objectives of profit maximization and targeting poverty, which are contradictory in practice. Such targeting (poverty) consumed $51.4 \%$ and $35.2 \%$ of profits from BRAC and Grameen Bank, respectively. Considering all these issues instead of full commercialization, responsive development is on its way to coping with the on-going demand. NGOs like ASA, BRAC, Proshika and others started a paradigm shift to new frontiers of microenterprise financing under various programme offers through the gradual expansion of lending to microfinance and even by shifting from group lending to individual lending. They started offering loans ranging from US\$ 320 to US\$ 6,700 (local currency: BDT 20,000 to BDT $4,000,000$ at that time), whereas the usual microfinance loan ranges from US\$ 70-425, (BDT 5,000-30,000).

At present, a loan amount up to BDT 50,000 is considered microcredit and above this limit as a microenterprise loan (Alamgir, 2009; MRA Overview, 2013; Zaman, 2004). Lending to SMEs, a slightly bigger "cousin" of the microenterprise, is not easy within existing financing practice. It is not small enough to attract microfinance and not sufficiently well documented to secure a commercial loan. Certainly, finance is not a charity and MFIs have to rely on subsidy or donations, at least at the beginning (Zaman, 2004; Zeller et al., 2001). After 2004, the MFIs of Bangladesh have reached a matured and saturated competitive stage. New-generation MFIs tend to be involved more in agricultural loans than in small business and housing loans. In this "new order competition", lenders are "spatially clustering", an indication of their sustainability efforts (Khandker et al., 2013; McIntosh, De Janvry and Sadoulet, 2004). Consequently, the up-scaling of the loan programme of BRAC failed to attract borrowers from the existing microcredit client pool due to unwillingness, whether self-exclusion or inability to meet the criteria, of the potential clients (Emran et al., 2006). It is evident that the market imperfection and the lack of demand creation are important. The vertical expansion (amount of scaling up) of loans may not fully match up with the horizontal (geographical distribution) expansion due to the distributive pattern of inequality and poverty across the country.

Nonetheless, the question of the NGO-MFI location factor is still to be explored. NGOs are non-profit organizations primarily guided by altruistic objectives. They may choose a poor area and may be dependent on donors who expect successes, and so they must find ways to avoid the risks of poor areas. 
The actual motivation in selecting programme locations is always unknown. MFIs expand credit programmes where they are absent, without considering other types of institutions that may be present; the unofficial information-sharing among them for "lending to the same person and selecting a programme in a same community of the village" is never followed (Gauri and Fruttero, 2003; Mallick and Nabin, 2011).

In one of the few studies that have been published, Gauri and Fruttero (2003) found that NGOs open programs in a village, create local know-how and then move to other villages, even though this move is not widely accepted while it is a credit programme. They also found that the presence of an NGO credit programme influences others to choose the same location because it indicates a market. Khandker et al. (1995) studied the performance and sustainability of Grameen Bank, the largest MFI in Bangladesh. They found that Grameen bank branch placement was not conditioned by its proximity to administrative centres; even agricultural production risk and flood prone issues were not found to be related with branch placement. Ravallion and Wodon (1997) found the same result and argued that Grameen Bank is attracted by areas where the gains favour the poor for giving them access to credit. Zeller et al. (2001) used thana-level data from the 1994 Statistical Yearbook of Bangladesh to identify the determinants of branch placement of MFIs - particularly BRAC, ASA and Proshika - and indicated that better access to transport, communication infrastructure and proximity to a commercial bank are preferred for branch placement. They also found that outreach is significantly higher in thanas that have a higher distress (flood, poverty) index, which is completely opposite to that of the placement equation and general trends.

Mallick and Nabin (2011) found that NGOs are primarily guided by altruism but that they also seek financial sustainability. NGO coverage decreases with the distance from the main marketplace in rural areas, as this distance is associated with poor physical infrastructure and few sustainable opportunities. They also cited an example of applied geography from BRAC. In 2010, BRAC launched a new lending programme covering 40 districts in the country. The implicit cut-off radius was $8 \mathrm{~km}$ from BRAC branch offices (located in nearby upazila headquarters). However, BRAC does not officially make this "cut-off radius" available.

Similarly, the South Africa charter adopted in 2004 had the target of bringing first-order financial services (savings, credit, etc.) within a $20 \mathrm{~km}$ radius of every South African (AFI, 2010). These issues of "Applied Geography" are highly involved with the agenda of financial inclusion as a global policy concern. Conceptually, the geographic distance to a financial services branch or the density of branches related to population is a crude measure of financial access (Beck et al., 2007). A few other studies support these findings, which are almost identical to the situation in Bangladesh. Pedrosa and Do (2008) analysed the relationship between the distance separating households from microfinance institutions in Niger and found that, to cope with the effects of geographical distance, microfinance institutions adapt their 
policies through more restrictive loan conditions, higher interest rates and more intensive screening. Presbitero and Rabellotti (2014) studied geographical distance and reached nearly the same conclusion regarding Colombia. Population density and physical infrastructure may have an effect on expanding MFIs in developing countries.

\section{Geographical Concentration/Distribution of Bank Branches and MFIs}

The geographical concentration/distribution of banks and MFIs (tables 3 and 4) is highly influenced by various "Economic Geography" factors. Regulatory requirements, political influence, physical infrastructure like road and communication, availability of utility services, economic activity of the area, income of the community, number of other financial institutions in the area, etc., are highly influential factors in attracting bank branches. There were 8,685 operating branches of 56 scheduled banks at the end of December 2013, of which $3,723(42.87 \%)$ were in urban areas and 4,962 (57.13\%) were in rural areas (Bangladesh Bank, 2013). Bangladesh has 67.59 commercial bank branches per 1,000 square kilometres and 8.19 branches per 100,000 adults. For automated teller machine (ATM) penetration, these values are 52.22 and 6.33, respectively (IMF website). By comparison, Spain has 96 branches and 101.46 ATMs per 100,000 people (Beck et al., 2007; CGAP and WBG, 2010).

However, these values are changing comparatively fast due to responsive global innovation in technology and policy structure. On the other hand, the number of MFIs is openly controversial because there are both licensed and non-licensed MFIs in the market. There are nearly 5,000 NGO-MFIs in Bangladesh, but at the end of 2013 only 730 NGOs had been licensed to operate microfinance services. Of these, the top 20 MFIs contribute more than $72 \%$ of total outstanding loans, deposits and borrowers (MRA Overview, 2013). A problem in comparing the MFI with banks is the data limitation of MFIs. NGOs are licensed/registered in various locations and with various organizations around the country, although since 2006 all NGO-MFIs are licensed by MRA. On the other hand, all the scheduled banks, except Rajshahi Krishi Unnoyon Bank, are registered in Dhaka, the capital city.

The above chart does not mean that the MFIs are growing at the rate shown; it reflects licensing by MRA, although they were established earlier. The two largest NGOs and Grameen Bank cover all districts but most of the NGOs are regionally arranged (MRA Overview, 2011).

Grameen Bank, the largest microfinance producer in Bangladesh, is not included in the above chart, although it had 2,567 branches across the country at the end of December 2013, covering 81,389 villages (Bangladesh Bank, 2013). For the last few decades, the development of physical infrastructure and the use of innovative communication technology in the sector may allow MFI branches to serve larger areas than before.

In urban areas, the coverage of state-owned banks in 2012 was $15.06 \%$ and private banks' was $24.86 \%$, while specialized banks represented only $2.1 \%$. 
Table 3. Division-wise distribution and growth of licensed NGO-MFIs (location of head offices) in June 2013

\begin{tabular}{|c|c|c|c|c|c|c|c|c|c|c|}
\hline \multirow[b]{2}{*}{ Division } & \multicolumn{2}{|c|}{ June 2009} & \multicolumn{2}{|c|}{ June 2010} & \multicolumn{2}{|c|}{ June 2011} & \multicolumn{2}{|c|}{ June 2012} & \multicolumn{2}{|c|}{ June 2013} \\
\hline & $\begin{array}{l}\text { No. of } \\
\text { offices }\end{array}$ & $\%$ & $\begin{array}{l}\text { No. of } \\
\text { offices }\end{array}$ & $\%$ & $\begin{array}{l}\text { No. of } \\
\text { offices }\end{array}$ & $\%$ & $\begin{array}{l}\text { No. of } \\
\text { offices }\end{array}$ & $\%$ & $\begin{array}{l}\text { No. of } \\
\text { offices }\end{array}$ & $\%$ \\
\hline Dhaka & 195 & 46.6 & 240 & 45.8 & 273 & 46.4 & 273 & 44.2 & 294 & 42.6 \\
\hline Rajshahi & 78 & 18.2 & 97 & 19.1 & 86 & 18.1 & 86 & 13.9 & 95 & 13.8 \\
\hline Rangpur** & - & - & - & - & 34 & - & 34 & 5.5 & 36 & 5.2 \\
\hline Khulna & 64 & 15.5 & 73 & 14.3 & 91 & 14.1 & 91 & 14.7 & 107 & 15.5 \\
\hline Chittagong & 51 & 12.1 & 66 & 12.8 & 92 & 14.0 & 92 & 14.9 & 106 & 15.4 \\
\hline Barisal & 23 & 5.6 & 30 & 5.9 & 32 & 5.7 & 32 & 5.2 & 38 & 5.5 \\
\hline Sylhet & 8 & 1.9 & 10 & 2.0 & 10 & 1.7 & 10 & 1.7 & 14 & 2.0 \\
\hline Total & 419 & 100 & 516 & 100 & 580 & 100 & 618 & 100 & 690 & 100 \\
\hline
\end{tabular}

Number of

Branches

16,851

17,252

18,066

17,977

14,674

${ }^{* *}$ Rangpur Division was created by dividing the Rajshahi Division.

Source: Annual Report 2013, MRA.

Table 4. Distribution (Urban \& Rural) of Scheduled Bank Branch in Bangladesh by Division as of December 31, 2012

\begin{tabular}{lrrrrrr}
\hline & \multicolumn{7}{c}{ Number of Branches } \\
\cline { 2 - 7 } \multicolumn{1}{c}{ Division } & Urban & $\begin{array}{c}\text { \% in } \\
\text { Division }\end{array}$ & \multicolumn{1}{c}{ Rural } & $\begin{array}{c}\text { \% in } \\
\text { Division }\end{array}$ & Total Div. & $\begin{array}{c}\text { \% of } \\
\text { Total Branch. }\end{array}$ \\
\hline Dhaka & 1,591 & 53.46 & 1,385 & 46.53 & 2,976 & 35.76 \\
Rajshahi & 321 & 34.66 & 605 & 65.33 & 926 & 11.13 \\
Khulna & 324 & 38.80 & 511 & 61.19 & 835 & 10.03 \\
Chittagong & 781 & 41.76 & 1,089 & 58.23 & 1,870 & 22.47 \\
Barisal & 128 & 30.26 & 295 & 69.73 & 423 & 5.09 \\
Sylhet & 220 & 32.21 & 463 & 67.78 & 683 & 8.20 \\
Rangpur & 197 & 32.34 & 412 & 67.65 & 609 & 7.32 \\
Total & 3,562 & 42.80 & 4,760 & 57.20 & 8,322 & 100.00 \\
\hline
\end{tabular}

Source: Scheduled Bank Statistics, Bangladesh Bank, Quarterly, October-December, 2013

However, specialized banks cover $15.20 \%$ of the total rural share, indicating that they expand to reach more rural settings. On the other hand, the rural share of state-owned and private banks is $26.74 \%$ and $15.26 \%$, respectively (Bangladesh Bank, 2013).

\section{Conclusions}

Uneven economic development, both in social and geographical distribution patterns, over time has created the existing image of spatial inequality in rendering financial services in Bangladesh. Much has been told about microcredit, but only some researchers have given importance to the financial 
needs of micro and small enterprises and rural farms. Undoubtedly, MFIs will never be able to serve all the poor borrowers on the fringes of the sphere of formal financial institutions. Therefore, the coexistence of formal and informal (traditional) institutions is a common feature of the developing world (Demont, 2010; Tressel, 2003). How do the financial intermediaries (i.e. banks and MFIs) present themselves along with their products and services to rural enterprises? This is an important matter to be explored. From our point of view, we identify it as the extent of geographical justification or financial democracy.

Due to various market principles with a view to catering to rural enterprise, neither could the commercial bank network be extended overnight to the most remote site nor could the MFIs be transformed or developed to the strength of full-fledged financial institutions overnight. The rural economic geography of Bangladesh, along with its financial institution pattern, cannot support the needs of rural enterprise, although this could improve because there is recognition of the problem. The experience through ups and downs shows that microfinance has little extra qualification to reach the most risky clients in rural remote areas. Resource accumulation in prospective urban centres and the market principles of financial institutions logically do not cater to rural enterprise in general. On the other hand, the resource constraints and stagnation in development politics at the national level have created ignorance about policy formulation for the disadvantaged rural areas. Researchers have opined that policymakers may consider for-profit microfinance providers if MFIs are already behaving much like profit-maximizing institutes in a mature market like Bangladesh (Salim, 2013). For the last few decades, microfinance institutions have met the financial needs of the "economic bottom-line classes" and micro-enterprises of rural Bangladesh. Banks and MFIs differ in regard to their economic strength, nature of performance, principles and social objectives. Considering the existing rural financial ecology and spatial arrangement of financial intermediaries, we need to find the problems and limitations of rural enterprise and farms as well as of financial institutions in order to create a demand-based financing environment.

Primarily, microfinance is gradually becoming a major source of funding for rural enterprises in the absence of bank branches, often as an area's only or sometimes comparatively better source of funds for that sector. For these enterprises, MFIs are present in the remote geographies, and are apt to deliver loans without a collateral requirement, unlike banks. However, the interest rate and loan term are not suitable for borrowers, who are being discriminated against in comparison to larger loans delivered by banks in nearby urban areas. The MFI growth and scaling-up of loan amounts in recent years invites new thoughts about sustainability and development.

As per our study objectives, even if up-scaling or down-scaling is considered to level the playing field, we must explore and compare these two types of institution, banks and MFIs. Experts hope that if an enabling environment can be created with appropriate methodology, private banks may 
begin to cater to the top end of the micro and small enterprise and MFIs could scale up to micro and small enterprise as well as marginal and small farmers (Ferrari, 2008). Which of them has an advantageous location and the "organization-wide facility" to provide rural enterprise with access to financial services? That is the central question. In-depth research from an Economic Geography perspective would help to develop guidelines to highlight the texture of the problem and the policy infrastructure required for proper rural development.

\section{Bibliographical references}

AFI (2010). Financial inclusion measurement for regulators: Survey design and implementation. Bangkok: Policy paper of Alliance for Financial Inclusion (AFI).

Agarwal, S.; Hauswald, R. (2010). "Distance and private information in lending", Review of Financial Studies, 23(7), 2757-2788.

$<$ http://dx.doi.org/10.1093/rfs/hhq001>

Ahlin, C.; Lin, J.; Maio, M. (2010). Where does microfinance flourish? Microfinance institution performance in macroeconomic context. Available at: $<$ https://www.msu.edu/ -ahlinc/research/mfimacro4.pdf> [accessed December 16, 2014)

Ahsan, A.H.M.K. (2010). Problems of Coordination in Local Administration in Bangladesh: Thesis (M. Phil) in Public Administration, Department of Administration and Organization Theory, University of Bergen, Norway.

Aladuwaka, S.; Momsen, J. (2013). “Micro-credit, Poverty Alleviation and Women's Empowerment: A case study from Rural Sri Lanka". In Momsen, Janet and Buang, Amriah (eds) Gender and Empowerment, University of Malaysia Press.

AlamÁ, L.; Tortosa, E. (2012). "Bank branch geographic location patterns in Spain: some implications for financial exclusion". Growth and Change, 43 (3), 505-543. $<$ http://dx.doi.org/10.1111/j.1468-2257.2012.00596.x>

Alamgir, D.A.H. (2009). State of Microfinance in Bangladesh; a paper prepared for Institute of Microfinance (InM), Bangladesh. Available at:

$<$ http://inm.org.bd/saarc/document/Bangladesh.pdf> [accessed December 16, 2014)

Alessandrini P.; Croci M.; Zazzaro, A. (2005). "The geography of banking power: the role of functional distance". Banca Nationale del Lavoro Quarterly Review, LVIII (235), 129-167.

Alessandrini, P.; Presbitero, A. F.; Zazzaro, A. (2010). "Bank Size or Distance: What Hampers Innovation Adoption by SMEs?" Journal of Economic Geography 10 (6), 845-881.

Appleyard, L. (2013). "The Geographies of Access to Enterprise Finance: The Case of the West Midlands, UK", Regional Studies 47(6), 868-79. <http://dx.doi.org/10.1080/00343404.2012.748979>

Armendariz, B.; Morduch, J. (2005). The Economics of Microfinance. Cambridge, MA: MIT Press.

Armendáriz, B.; Roome, N. (2008). "Gender Empowerment in Microfinance", in Suresh Sundaresan (ed.), Micro-Finance, Investment Trends and Challenges. New York: Edward Elgar Publishing, Ltd. 
Bangladesh Bank (2013). Scheduled Banks Statistics, October-December, from 1998 to 2013, Bangladesh Bank, Dhaka.

BBS (2011). Statistical Pocket Book of Bangladesh-2010, Bangladesh Bureau of Statistics, Dhaka.

Beck, T.; De La Torre, A. (2007). "The Basic Analytics of Access to Financial Services". Financial Markets, Institutions and Instruments, 16, 79-117. <http://dx.doi.org/10.1111/j.1468-0416.2007.00120.x>

Beck, T.; Demirgüç-Kunt, A. (2008). “Access to Finance: An Unfinished Agenda”. World Bank Economic Review, 22(3), 383-396. <http://dx.doi.org/10.1093/wber/lhn021>

Beck, T.; Demirgüç-Kunt, A.; Honohan, P. (2009). "Access to Financial Services: Measurement, Impact and Policies”. World Bank Research Observer, 24 (1), 119-145. <http://dx.doi.org/10.1093/wbro/lkn008>

Beck, T.; Demirgüç-Kunt, A.; Peria, M.S.M. (2007). "Reaching Out: Access to and Use of Banking Services across Countries" Journal of Financial Economics, 85(1), 234-66. <http://dx.doi.org/10.1016/j.jfineco.2006.07.002>

- (2008). "Banking services for everyone? Barriers to bank access and use around the world". The World Bank Economic Review, 22(3), 397-430. <http://dx.doi.org/10.1093/wber/lhn020>

Berger, A.N.; Udell, G.F. (1995). "Relationship Lending and Lines of Credit in Small Firm Finance". Journal of Business, University of Chicago Press, 68(3), 351-381.

- (2006). "A More Complete Conceptual Framework for SME Finance”. Journal of Banking \& Finance, 30, (11), 2945-2966 <http://dx.doi.org/10.1016/j.jbankfin.2006.05.008>

Carbó-Valverde.S.; Rodríguez-Fernández, F.; Udell, G.F. (2009). "Bank Market Power and SME Financing Constraints". Review of Finance, 13(2), 309-340 Available at: <http://www.ugr.es/ franrod/WPCRU.pdf> [accessed June 10, 2014]

CGAP and the WORLD BANK GROUP (WBG) (2010). Financial Access 2010: The State of Financial Inclusion through the Crisis. Washington DC: The World Bank Group.

Chakravarty, S., Shahriar, A. Z (2010). Relationship Lending in Microcredit: Evidence from Bangladesh. Available at: <http://www.rug.nl/research/events/workshopmicrofinance2010/pdfmicro/chakravartyshahriar.pdf> [accessed December 16, 2014)

Charitonenko, S.; Rahman, S.M. (2002). Commercialization of Microfinance: Bangladesh, Manila: Asian Development Bank.

Chaves, R.; Gonzalez-Vega, C. (1996). "The Design of Successful Rural Financial Intermediaries: Evidence from Indonesia”. World Development. 24(1): 65-78. <http://dx.doi.org/10.1016/0305-750X(95)00114-R>

Clarke, G.; Cull, R.; Peria, M.S.M.; Sanchez. S.M. (2005). "Bank Lending to Small Businesses in Latin America: Does Bank Origin Matter? "Journal of Money, Credit and Banking, 37(1): 83-118. <http://dx.doi.org/10.1353/mcb.2005.0003>

Cull. R.; Demirgüç-Kunt A.; Morduch. J. (2009). "Microfinance Meets the Market" Journal of Economic Perspectives, 23 (1), 167-192. <http://dx.doi.org/10.1257/jep.23.1.167> 
Demont, T. (2010). The Impact of Microfinance on the Informal Credit Market: An Adverse Selection Mode. CRED Working Paper 2010/05, University of Namur. Belgium.

Demirgüç-Kunt, A.; KLapper, L. (2012). Measuring Financial Inclusion: The Global Findex Database. Policy Research Working Paper 6025, Washington, DC: The World Bk.

Dymsкi, G.A. (2013). "Can Relationship Banking Survive the Spanish Economic Crisis?” Ekonomiaz, 84 (03), 182-205.

Emran, M. S.; Morshed, A.K.M.M.; Stiglitz, J. E. (2006). Microfinance and Missing Markets. Available at: <http://www.researchgate.net/publication/228168314_ Microfinance_and_Missing_Markets> [accessed August 13, 2013]

Faruqee, R. (2010). Microfinance for Agriculture in Bangladesh: Current Status and Future Potential. Working Paper No. 08, Dhaka: Institute of Microfinance.

Ferrari, A. (2008). Increasing Access to Rural Finance in Bangladesh: The Forgotten Missing Middle. A study conducted by World Bank, Led by Ferrari, A. Washington DF.

Gärtner, S.; Flögel, F. (2014). Call for a Spatial Classification of Banking Systems through the Lens of SME Finance - Decentralized versus Centralized Banking in Germany as an Example. Discussion Paper, 14/01, Institute for Work and Technology. Westphalian University of Applied Sciences, Germany.

Gauri, V.; Fruttero, A. (2003). Location Decisions and Nongovernmental Organization Motivation: Evidence from Rural Bangladesh. Policy Research Working Paper no. 3176, Washington DC: The World Bank.

Gonzalez-Vega, C.M.; Schreiner, R.L.; Meyer, J.; Rodriguez-Meza.; Navajas, S. (1996). "Bancosol: The Challenge of Growth for Microfinance Organizations", in Hermut Schneider (ed) Microfinance For the Poor?

Hoff, K.; Stiglitz. J.E. (1993). "Imperfect information and Rural Credit Markets: Puzzles and Policy Perspectives”, in: Hoff, K.; Braverman, A.; Stiglitz, J.E. (eds.), The Economics of rural Organization: Theory, Practice and Policy, New York: Oxford University Press.

Hossain, M. (2004). Rural Non-Farm Economy in Bangladesh: A View from Household Surveys. Occasional Paper No. 40, Dhaka: Centre for Policy Dialogue.

IFC and KFW (2009). Microfinance and Financial Sector Diagnostic Study, a report. In: <http://hofinet.org/upload_docs/Bangladesh_Microfinance\%20and\%20Financial\%20Sector\%20Diagnostic\%20Study.pdf> [accessed December 16, 2014]

IMF: Online IMF Financial Survey data (Existing). Available at: <http://fas.imf.org/ Home.aspx> [accessed December 16, 2014]

Juan, R. (2002). "Entry in Independent Submarkets: An Application to the Spanish Retail Banking Market". The Economic and Social Review, 33 (1), 109-118.

Kato, M.P.; Kratzer, J. (2013). "Empowering Women through Microfinance: Evidence from Tanzania". ACRN Journal of Entrepreneurship Perspectives. 2, (1): 31-59.

Khandker, S.R.; Khalily. M.A.B.; Khan. Z. (1995). Grameen Bank: Performance and Sustainability. Discussion Paper no. 306, Washington, D.C.: the World Bank.

Karim, L. (2008). "Demystifying Micro-credit: The Grameen Bank, NGOs, and Neoliberalism in Bangladesh". Cultural Dynamics, 20 (1), 5-29. <http://dx.doi.org/10.1177/0921374007088053>

Khandker, S.R.; Koolwal G.B.; Badruddoza, S. (2013). How Does Competition Affect the Performance of MFIs? Policy Research Working Paper no. 6408, Washington DC: The World Bank. 
Keeble, D. (1990). "Small firms, new firms and uneven development in the United Kingdom”. Area, 22, 234-245.

Klagge, B.; Martin, R. (2005). "Decentralized versus centralized financial systems: is there a case for local capital markets?" Journal of Economic Geography, 5 (4), 387-421. <http://dx.doi.org/10.1093/jeg/lbh071>

Krueger, R. (2010). "Smart Growth and Its Discontents: An examination of American and European Approaches to Local and Regional Sustainable Development". Documents d'Anàlisi Geogràfica, 56 (3), 409-433.

Leyshon, A.; Thrift, N. (1994). Geographies of financial exclusion: financial abandonment in Britain and the United States, Department of Geography, University of Bristol, Bristol BS8 1SS.

Li, X.; Xiongfei, Z. (2008). "Institutional Reforms and the Spatial Evolution of Banking System in a Less Developed Region of China since 1978". Development and Society, 37 (1), 55-76. Available at: $<$ http://isdpr.org/isdpr/publication/journal/37-1/03.pdf [accessed December 16, 2014]

Mallick, D.; Nabin. M.H. (2011). Where NGOs go and Do not go? Research Monograph Series no. 45, Research and Evaluation Division, BRAC, Bangladesh.

MAP. Available at: <http://mapsof.net/map/bangladesh-districts> [accessed December 4, 2014]

Marshall, J.N. (2004). "Financial institutions in disadvantaged areas: a comparative analysis of policies encouraging financial inclusion in Britain and the United States". Environment and Planning A, (36), 241-261. <http://dx.doi.org/10.1068/a3664>

Martin, R. (ed.) (1999). Money and the Space Economy. London: John Wiley \& Sons.

Martin, R.; Berndt, C.; Klagge, B.; Sunley, P. (2005). "Spatial proximity effects and regional equity gaps in the venture capital market: evidence from Germany and the United Kingdom". Environment and Planning A (37), 1207-1231. <http://dx.doi.org/10.1068/a3714>

Massey, D. (2009). "Concepts of space and power in theory and in political practice". Documents d'Anàlisi Geogràfica, 55, 15-26.

McIntosh, C.; De Janvry, A.; Sadoulet, A. (2004). "How Rising Competition among Microfinance Institutions Affects Incumbent Lenders". The Economic Journal, 115, 987-1004. <http://dx.doi.org/10.1111/j.1468-0297.2005.01028.x>

Mondol, M.H. (2010). "Crop Agriculture of Bangladesh: Challenges and Opportunities”. Bangladesh Journal of Agricultural Research, 35(2), 235-245.

MRA (Microcredit Regulatory Authority, 2010). NGO-MFIs in Bangladesh: A Statistical Publication. Volume 6, June 2009, Dhaka: MRA.

MRA (2011). NGO-MFIs in Bangladesh: A Statistical Publication. Volume 7, June 2010, Dhaka: MRA.

MRA (2011). Annual Report. Dhaka: MRA.

MRA (2013). Annual Report. Dhaka: MRA.

MRA Overview, Available at: <http://www.mra.gov.bd/> [accessed October 1, 2014]

Pandula, G. (2011). "An empirical investigation of small and medium enterprise' access to bank finance: the case of an emerging economy", Proceedings of ASBBS, 18 (1), 255-273. Annual Conference: Las Vegas.

Paul, S.; Goel, P.R. (2010). Decentralization in Bangladesh. NCAER New-Delhi. <http://www.ruralgovncaer.org/images/product/doc/13_515740412_Decentralization-in-Bangladesh.pdf> [accessed June 16, 2014] 
Pedrosa, J.; Do, Q. (2008). How Does Geographic Distance Affect Credit Market Access in Niger? Policy Research Working Paper no. 4772. Washington DC: The World Bank.

Pellegrina, L.D. (2011). "Microfinance and Investment: a Comparison with Bank and Informal Lending". World Development, 39 (6), 882-897. <http://dx.doi.org/10.1016/j.worlddev.2011.03.002>

Petersen, M.A.; Rajan, R.G. (1994). "The benefits of lending relationships - Evidence from small business data" Journal of Finance, 49 (1), 03-37.

- (1995). "The effect of credit market competition on lending relationships". Quarterly Journal of Economics, 110 (2), 407-443.

<http://dx.doi.org/10.2307/2118445>

- (2002). "Does distance still matter? The information revolution in small business lending". Journal of Finance, 57.

Polese, M.; Shearmur, R. (2004). "Culture, language, and the location of high-order service functions: the case of Montreal and Toronto". Economic Geography, 80 (4), 329-350.

<http://dx.doi.org/10.1111/j.1944-8287.2004.tb00241.x>

Presbitero, A.F.; Rabellotti, R. (2014). "Geographical Distance and Moral Hazard in Microcredit: Evidence from Colombia”. Journal of International Development, 26 (1), 91-108. <http://dx.doi.org/10.1002/jid.2901>

Ravallion, M.; Wodon, Q. (1997). Banking on the Poor? Branch Placement and Nonfarm Rural Development in Bangladesh. Policy Research Working Paper no. 1858, Washington DC: The World Bank.

Rhyne, E.; Christen, R.P. (1999). "Microfinance Enters the Marketplace”. Washington, D. C.: USAID Microenterprise Publications.

Salim, M.M. (2013). "Revealed Objective Functions of Microfinance Institutions: Evidence from Bangladesh”. Journal of Development Economics, 104 (C), 34-55. <http://dx.doi.org/10.1016/j.jdeveco.2013.03.011>

Stiglitz, J.E. (1990). "Peer Monitoring and Credit Markets". The World Bank Economic Review, 4(3), 351-366. <http://dx.doi.org/10.1093/wber/4.3.351>

SOUTH ASIA.PDF: <https://geography.byu.edu/Assets/Maps/soasia.pdf> [accessed December 16, 2014]

Tressel, T. (2003). "Dual Financial Systems and the Inequalities in Economic Development". Journal of Economic Growth, 8, 223-257. <http://dx.doi.org/10.1023/A:1024464506029>

Uchida, H.; Udell, G.F.; YAMORI, N. (2006). SME financing and the choice of lending technology. Discussion Paper Series 06-E-025, Research Institute of Economy Trade and Industry, (RIETI), Japan.

UNDP (2012). UNDP Country Profile. Available at: <http://data.un.org/CountryProfile.aspx?crName=Bangladesh $>$ [accessed December 16, 2014 ].

Uzzi, B. (1999). "Embeddedness in the making of financial capital: how social relations and networks benefit firms seeking finance". American Sociological Review, 64: 481-505. <http://dx.doi.org/10.2307/2657252>

World Bank (2007). Finance for All? Policies and Pitfalls in Expanding Access. Policy Research Report, Washington, DC: World Bank. 
Zaman, H. (2004) The Scaling - Up of Microfinance in Bangladesh: Determinants, Impact and Lesson. Policy research Working Paper 3398, Washington DC: The World Bank.

Zeller, M.; Sharma, M.; Ahmed, A.U.; Rashid, S. (2001). Group-Based Financial Institutions for the Rural Poor in Bangladesh: An Institutional and Household-Level Analysis, Research report-120, Washington DC: International Food Policy research Institute. 